\title{
Аналіз чинників, що впливають на ефективність функціонування пункту управління артилерійською розвідкою
}

\section{Олександр Таранець ${ }^{\text {; }}$ Микола Дорофєєв ${ }^{\mathrm{B}}$}

Received: May 6, 2020 | Revised: June 15, 2020 | Accepted: June 30, 2020

DOI: $10.33445 /$ sds.2020.10.3.12

\begin{abstract}
Анотація
Кожна війна або збройний конфлікт вносить суттєві корективи у форми і способи застосування військ (сил). Але загальним залишається те, що успіх у протиборстві залежить від уміння та можливості однієї зі сторін завдати іншій максимально можливого ураження живої сили та техніки. Основна роль у виконанні цього завдання належить засобам вогневого ураження, серед яких особливе місце посідають артилерійські засоби. Ефективність вогневого ураження противника прямо пропорційно залежить від спроможності розвідувальних підрозділів добувати та забезпечувати підрозділи вогневого ураження своєчасною та точною інформацією про об'єкти ураження (цілі). Тому розгляд питання удосконалення розвідки (артилерійської розвідки) в інтересах забезпечення участі військових частин і підрозділів ракетних військ і артилерії у вогневому ураженні противника в сучасних умовах $є$ актуальним.
\end{abstract}

Ключові слова: розвідка, артилерійська розвідка, засоби вогневого ураження, пункт управління артилерійською розвідкою, система бойового управління, розвідувальновогневий комплекс.

\section{Постановка проблеми}

Під час оцінювання ефективності застосування пункту управління артилерійською розвідкою (ПУАР) необхідно виявити ступінь залежності від об'єктивних та суб'єктивних чинників, встановити механізм їх впливу на функціонування ПУАР.

Під ефективністю функціонування ПУАР в ході ведення операцій (бойових дій) будемо розуміти таку характеристику, яка відображає ступінь пристосованості до свого цільового призначення - головну, цільову властивість системи, що забезпечує досягнення мети артилерійської розвідки (АР), а отже і мети операції (бойових дій) 3 найменшими втратами [1; 2].

\section{Аналіз останніх досліджень та публікацій}

Проведений аналіз літератури [3; 4; 5] свідчить, що характерними тенденціями сучасної збройної боротьби, які безпосередньо впливають на роботу ПУАР, в цілому можна вважати: перехід до мережецентричної концепції ведення воєнних дій; зростання просторового розмаху і динамізму збройної боротьби; глобалізацію систем розвідки, управління та навігації; зростання ролі інформаційної боротьби, кібернетичних дій у конфліктах і війнах майбутнього; скорочення часових показників на підготовку до ведення

\footnotetext{
А Науково-дослідний центр ракетних військ і артилерії, Суми, провідний науковий співробітник науково-дослідного відділу (наукового супроводження бойового застосування ракетних військ і артилерії), e-mail: ant505@ukr.net, ORCID: 0000-0002-3011-9091

в Центральний науково-дослідний інститут озброєння та військової техніки ЗСУ, м. Київ, ад’юнкт, e-mail: dorofeev83@meta.ua, ORCID: 00000001-8607-2483
} 
воєнних дій; забезпечення якісно нового рівня інформаційної сумісності систем розвідки, контролю, навігації, управління та різних ударних засобів і комплексів; інтеграцію засобів розвідки, ураження, управління та радіоелектронної боротьби в радіоелектронно вогневі системи, які забезпечуються інформацією та управляються в масштабі часу, наближеному до реального.

\section{Виклад основного матеріалу}

Сукупність чинників, що впливають на ефективність функціонування ПУАР пропонується розмежувати на зовнішні та внутрішні (рис. 1).

Внутрішніми чинниками

$\epsilon$ : укомплектованість органів управління AP, їх рівень фахової підготовки, обладнання пунктів управління згідно сучасних вимог, укомплектованість технічними засобами, їх тактико-технічні характеристики, забезпеченість засобами зв'язку та автоматизованою системою управління, наявність і якість спеціального програмного забезпечення, тощо [1; 2].

Зовнішніми чинниками $є:$ фізикогеографічні умови району ведення операції (бойових дій), кліматичні умови, пора року, час доби, характер дій військ противника, їх можливості щодо вогневого ураження елементів системи управління (пунктів управління), ставлення місцевого населення до збройних сил, масштаб району проведення операції (бойових дій), тощо [6].

У свою чергу перелічені чинники поділяється на дві групи: некеровані та керовані. До некерованих чинників, наприклад, відносяться об'єктивні закони природи і загального розвитку: характеристики району ведення операції (бойових дій); можливості сил противника; метрологічні умови, пора року, час доби; масштаб району операції проведення операції; завдання, умови, терміни та обмеження в ході ведення операції.
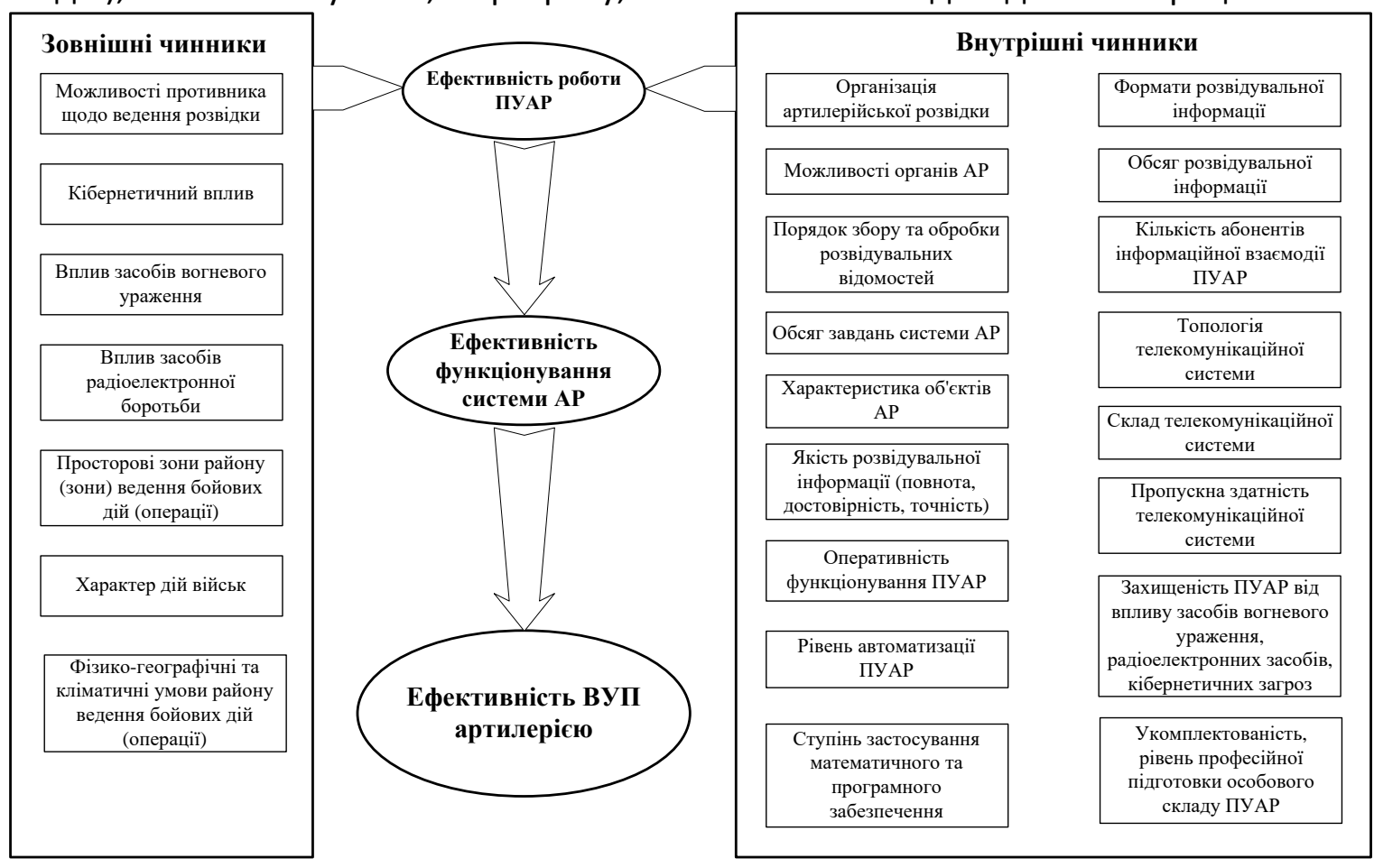

Мал. 1 - Чинники що впливають на ефективність роботи ПУАР

Проаналізуємо більш детально чинники, що впливають на ефективність роботи ПУАР.
1. Вплив зовнішніх чинників на ефективність роботи ПУАР 
Можливості противника щодо ведення розвідки. Даний чинник визначає перелік важливих (критичних) об'єктів системи АР, які противник здатний розвідати та за який час.

Кібернетичний вплив. У сучасних умовах використовується для здійснення впливу як на інформацію (спотворення інформації, знищення або внесення хибної інформації, ведення розвідки), так і на телекомунікаційні мережі (ТКМ) шляхом створення перевантаження мережі, порушення маршрутизації або виведення 3 ладу телекомунікаційного обладнання чи серверів тощо.

Вплив засобів вогневого ураження. Цей фактор визначає можливості вогневого впливу противника на важливі (критичні) об'єкти системи АР, дезорганізацію систем управління та артилерійської розвідки.

\section{Вплив засобів радіоелектронної} боротьби. Вплив засобів вогневого ураження, радіоелектронної боротьби та кібернетичного впливу суттєво зменшують ефективність функціонування ПУАР за рахунок зменшення пропускної здатності TKM, що в свою чергу впливає на оперативність управління артилерійською розвідкою [7].

Просторові розміри зони (району) бойових дій (операції). Впливають на протяжність ТKM, їі структуру та кількість телекомунікаційного обладнання і, як наслідок, на середній час проходження розвідувальної інформації та команд (сигналів) управління.

Характер дій військ. Від виду бойових дій буде залежати співвідношення дротових та бездротових каналів зв'язку [8]. Від характеру дій військ буде залежати стійкість ТКМ до вогневого, радіоелектронного та кібернетичного впливу та, відповідно, пропускна здатність ПУАР.

Фізико-географічні та кліматичні умови зони (району) проведення бойових дій (операції). Можуть створювати перешкоди під час організації зв' язку. Зазначений фактор при правильному врахуванні може позитивно впливати на ефективність функціонування ПУАР.
При проведенні планування АР обов'язково потрібно враховувати вплив зовнішніх чинників на функціонування ПУАР у ході проведення бойових дій (операції).

2. Вплив внутрішніх чинників на ефективність роботи ПУАР

Організація артилерійської розвідки. Ефективність функціонування ПУАР багато в чому залежить від якості організації АР артилерійськими командирами та штабами усіх інстанцій. До чинників, що характеризують організацію і ведення АР відносяться: час ведення розвідки; райони та висота польотів засобів повітряної розвідки; стан сил і засобів АР, розподіл їх за завданнями, рубежами і напрямами; порядок збору і способи обробки розвідувальних відомостей ПУАР.

Можливості органів (засобів) АР. Даний чинник оказує вплив на достовірність, повноту, точність та оперативність розвідувальних відомостей які надходять до ПУАР.

Можливості засобів розвідки щодо вимог точності визначення координат об`єктів (цілей) для ураження вогнем артилерії характеризуються помилками визначення координат об'єктів (цілей), які в цілому відповідають вимогам РВіА щодо точності їх визначення [9].

Порядок збору і обробки розвідувальних відомостей. Способи обробки розвідувальних відомостей, які на даний час застосовуються на ПУАР, значно збільшують час з моменту виявлення об'єкту противника до прийняття рішення на його ураження, i тому знижують якість розвідувальних даних.

Ухвалення рішення по сукупності розвідувальних ознак і використання автоматичних алгоритмів визначення місця розташування цілі може істотно підвищити достовірність розвідувальних відомостей [10]. Це досягається шляхом передачі i комплексної обробки розвідувальних відомостей, що поступають від різних (різнорідних) засобів розвідки на ПУАР. Відповідно стає можливим формування єдиного інформаційного поля В смузі загальновійськового формування, що 
дозволить підвищити якість оцінювання обстановки і обґрунтованість рішень, що приймаються командуванням. Тому в першу чергу доцільно автоматизувати процеси функціонування і передачі розвідувальних відомостей в комплексах і засобах розвідки, що замикаються на ПУАР.

Обсяг завдань системи АР. Обсяг завдань системи AP може виражатися кількістю об'єктів, що становлять обсяг завдань ВУП артилерією в бою. Даний чинник впливає на актуальність розвідувальних даних, що характеризують поточну ситуацію, ступінь відповідності розвідувальної інформації вимогам поточного часу або певного часового періоду. Достовірна і адекватна, але застаріла інформація може приводити до помилкових рішень.

Характеристика об'єктів АР. Повнота розкриття характеристик об'єктів ураження суттєво впливає на якість розвідувальної інформації і на достатність даних для прийняття рішень або для створення нових даних на основі наявних. Неточна інформація - недостатні, неточні, неповні відомості про об'єкт.

Якість розвідувальної інформації (повнота, достовірність, точність).

Повнота розвідувальної інформації властивість інформації, яка вказує на міру відповідності отриманих розвідувальних даних тому змісту і об єму який необхідний для підготовки вогню артилерії.

Достовірність розвідувальної інформації іiі дійсність та відповідність бойовій обстановці. Достовірність розвідувальної інформації, як і ії повнота, є складовими прийняття вірного рішення артилерійським командиром (начальником). Достовірність розвідувальних відомостей визначається шляхом їх зіставлення з обстановкою, що реально склалася, а також з наявними на ПУАР відомостями з урахуванням надійності джерел. За ступенем достовірності відомості можуть бути достовірними, можливими, сумнівними і удаваними.

Точність визначення координат об'єктів (цілей) противника полягає у встановленні їх координат з помилками, що не перевищують необхідний рівень та забезпечують ефективне застосування засобів ураження, i досягається застосуванням сучасних засобів артилерійської розвідки [11].

Оперативність функціонування ПУАР під час збору та обробки розвідувальних відомостей. Ефективність функціонування ПУАР напряму залежить від оперативності (своєчасності) отримання необхідних розвідувальних даних артилерійськими командирами (начальниками).

Частковими показниками оперативності в даному випадку $\epsilon$ час розгортання розвідувальних засобів на позиції та підготовки до розвідки, час на один цикл виконання розвідувального завдання та час передачі розвідданих до зацікавлених інстанцій [12]. Величини даних часткових показників обумовлені тактико-технічними характеристиками розвідувальних засобів та засобів зв'язку, можливостями ПУАР щодо збору і обробки розвідувальних відомостей, підготовкою обслуговуючого персоналу i дорівнюють: час одного циклу виконання розвідувального завдання $\left(t_{\mathrm{p}}\right)$; час передачі розвідувальних відомостей до ПУАР $\left(t_{п}\right)$; час обробки розвідувальних відомостей на ПУАР $\left(t_{\text {обр }}\right)$.

За узагальнений показник оцінювання оперативності функціонування ПУАР під час збору та обробки розвідувальних відомостей пропонується прийняти ймовірність своєчасності розвідувальних даних.

Оперативність функціонування ПУАР $\left(t_{\text {обр }}\right)$ впливає на час старіння розвідувальних даних і можливість залишення об'єктом (ціллю) місця, яке він займає до початку його ураження.

Швидкість старіння інформації $\left(\mathrm{T}_{\mathrm{cT}}\right)$ складається 3:

$$
\mathrm{T}_{\mathrm{cт}}=t_{\mathrm{p}}+t_{\Pi}+t_{\text {обр }}+t_{\text {пв }}
$$

де, $t_{\text {вп }}-$ час підготовки до відкриття вогню вогневими підрозділами.

Рівень автоматизації ПУАР. Він полягає у насиченості органів і пунктів управління, системи зв'язку, джерел інформації та спеціальних систем її збирання й оброблення засобами автоматизації. Розглядаючи рівень 
автоматизації, доцільно мати не кількість засобів автоматизації, а кількість автоматизованих функцій. За загально прийнятою практикою, розрізняють три рівні автоматизації: 50\% - 65\% - задовільний; $65 \%$ - $75 \%$ - добрий; 75\% та більше відмінний [7].

Недостатність особового складу ПУАР та низький рівень автоматизації роботи приводить до того, що оперативність організації АР в 2-2,5 рази, а збору і обробки розвідувальних відомостей (даних) у 8-10 разів відстає від армій провідних у військовому відношенні країн світу [11].

Використання АСУ для управління системою АР значно підвищує оперативність управління за рахунок зменшення часу на збирання, оброблення, розподіл розвідувальної інформації, прийняття рішення та планування і доведення рішень. У серед- ньому тривалість циклу управління на оперативному рівні скорочується в 3-4 рази [7].

Ступінь застосування математичного та програмного забезпечення.

Аналіз досвіду проведення командноштабних навчань підтвердив, що службові особи органів управління не в змозі фізично справитися з тим об'ємом інформації, якій потрібно їм опрацювати у визначений термін. У результаті проведення деяких експериментів в ході командно-штабних навчань, у яких брали участь службові особи органів управління, частина з них обробляла інформацію без використання спеціального програмного забезпечення, часові показники $(t)$ обробки інформації (I) значно відрізнялися від тих, які могли би бути у разі застосування спеціального програмного забезпечення (рис. 2) [6].

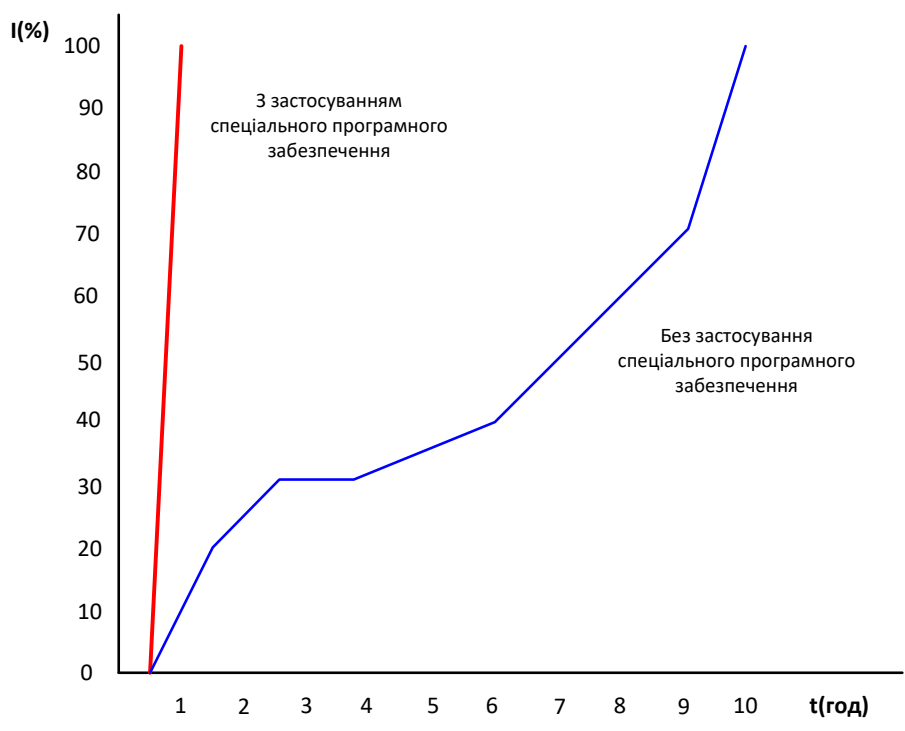

Рис. 2. Залежність часу обробки інформації від використання

(невикористання) спеціального програмного забезпечення

Формати розвідувальної інформації. Під форматом даних розуміється формат представлення розвідувальної інформації, а саме: аудіо, відео, фото, текстовий. Формат даних суттєво впливає на пропускну здатність телекомунікаційної мережі (TKM) та відповідно на ефективність функціонування інформаційно-телекомунікаційного забезпечення АСУ, спосіб та час оброблення даних, обсяг, який будуть вони займати в базі даних, а також на зручність їх формалізації.
Обсяг розвідувальної інформації. Залежить від кількості користувачів, якості інформації, формату даних, оперативної обстановки. Впливає на пропускну здатність TKM та час проходження інформації. Здійснює складний вплив на ефективність функціонування ПУАР.

Кількість абонентів інформаційної взаємодії ПУАР. Кількість абонентів впливає на швидкість передачі розвідувальної інформації та команд (сигналів) управління, 
структуру та склад ТКМ. Крім того, зростання кількості абонентів збільшує навантаження на сервери баз даних.

Топологія телекомунікаційної системи. Цей фактор впливає на живучість ТКМ та ресурси, які потрібні для розгортання та обслуговування цієї мережі. Розрізняють наступні варіанти: централізована, ієрархічна, децентралізована та розподілена [13].

Кожна 3 наведених топологій має певні переваги і недоліки, основні з яких наведені в табл. 1.

Таблиця 1 - Порівняльна характеристика топологій ТКМ системи АР

\begin{tabular}{|c|c|c|}
\hline Варіант т & Переваги & Недоліки \\
\hline $\begin{array}{c}\text { Централізована } \\
\text { (зіркоподібна) } \\
\text { топологія }\end{array}$ & $\begin{array}{l}\text { висока надійність та живучість; } \\
\text { значний рівень захисту від } \\
\text { несанкціонованого доступу (НСД); } \\
\text { висока швидкість обміну даними; } \\
\text { спрощене нарощування структури } \\
\text { мережі; } \\
\text { можливість роботи в реальному } \\
\text { масштабі часу; } \\
\text { простий доступ для обслуговування; } \\
\text { розміри мережі не обмежені. }\end{array}$ & $\begin{array}{l}\text { велике навантаження на } \\
\text { центральний вузол; } \\
\text { надійність та живучість мережі } \\
\text { напряму залежить від надійності } \\
\text { та живучості концентратора; } \\
\text { продуктивність тКМ } \\
\text { визначається } \\
\text { сервера. }\end{array}$ \\
\hline $\begin{array}{c}\text { Ієрархічна } \\
\text { (деревоподібна) } \\
\text { топологія }\end{array}$ & $\begin{array}{l}\text { простота побудови; } \\
\text { зрозумілий маршрут проходження } \\
\text { розвідувальної інформації; } \\
\text { зменшення ймовірності витоку } \\
\text { інформації; } \\
\text { системна стійкість до впливів; } \\
\text { здатність до реорганізації. }\end{array}$ & \begin{tabular}{lc}
\multicolumn{1}{c}{ збільшення } & часу \\
проходження & розвідувальної \\
інформації; & \\
можливе & спотворення \\
розвідувальної & інформації при \\
досягненні вищого рівня ієрархії; \\
складна побудова; \\
ресурсозатратність.
\end{tabular} \\
\hline $\begin{array}{c}\text { Розподілена } \\
\text { топології }\end{array}$ & 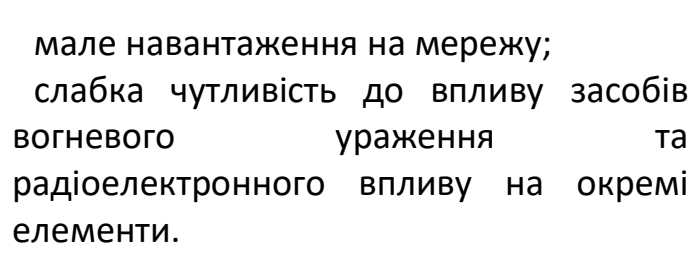 & $\begin{array}{l}\text { складність побудови та } \\
\text { управління; } \\
\text { ресурсозатратність; } \\
\text { вразливість до дезінформації } \\
\text { через складність перевірки } \\
\text { інформації. }\end{array}$ \\
\hline
\end{tabular}

Склад ТКМ. Впливає на живучість системи AР. Раціональний склад ТКМ підвищує ефективність функціонування ПУАР.

Пропускна здатність ТКМ. Пропускна здатність здійснює вплив на спроможність TKM забезпечувати обслуговування заданих потоків повідомлень на інформаційних напрямках. Ефективність функціонування ПУАР прямо пропорційна пропускній здатності TKM [7].

Захищеність ТКМ від впливу засобів вогневого ураження, радіоелектронних засобів, кібернетичних загроз. Впливає на пропускну здатність TKM, якість розвідувальної інформації та оперативність управління АР. Збільшення захищеності TKM позитивно впливає на ефективність функціонування ПУАР.

Укомплектованість, рівень професійної підготовки особового складу ПУАР. Ефективність функціонування ПУАР чимало залежить від наявності особового складу для виконання робіт за призначенням. Тому визначення раціонального складу ПУАР $€$ важливим і актуальним завданням, яке має як практичне, так і теоретичне значення.

Звичайно для порядку обгрунтування порядку виконання робіт на пунктах управління застосовується метод сітьового планування [14], який дозволяє визначити критичний шлях виконання робіт. При застосуванні цього методу використовуються часові оцінки (нормативи) тривалості і 
виконання робіт особовим складом ПУАР. Однак мало уваги приділяється визначенню потрібного складу ПУАР для виконання робіт за призначенням, зокрема не у повній мірі ураховується рівень кваліфікації особового складу, необхідність одночасного (паралелізм) виконання декількох робіт. Тому необхідно удосконалення методичних положень обгрунтування потрібного складу ПУАР для виконання робіт за призначенням.

\section{Висновки}

Таким чином, вказані вище зовнішні та внутрішні чинники суттєво впливають на ефективність функціонування ПУАР. Порушення функціонування ПУАР призведе до неможливості централізованого управління системою АР та окремими органами розвідки. Тому обов'язково потрібно враховувати вплив цих чинників 3 метою ефективного функціонування ПУАР i, відповідно, ефективного вогневого ураження противника артилерією у цілому.

Результати аналізу даних чинників застосувати під час формування показників ефективності функціонування ПУАР.

\section{Список використаних джерел}

1. Основы теории управления войсками / под ред. П. К. Алтухова. - М. :Военное издательство, 1984. - 222 с.

2. Вервейко Б. М., Гульбис С. К. Оценка эффективности функционирования системы управления войсками. Наука и военная безопасность. 2006. № 4.

3. Ярош С. П. Теоретичні основи побудови та застосування розвідувально-управляючих інформаційних систем протиповітряної оборони: монографія / С. П. Ярош; за ред. І. О. Кириченка. - Х.: ХУПС, 2012. - 512 с.

4. Магась Г. А. Тенденції розвитку збройної боротьби у сучасних умовах. Збірник наукових праць Національної академії Державної прикордонної служби України. Серія: військові та технічні науки. Хмельницький: 2015. №1(63). С. 79-95.

5. Joint Publication 6-0, Doctrine for Command, Control, Communications, and Computer (C4) Systems Support to Joint Operations. 1995. $88 \mathrm{c}$.

6. Мозговий Р. Аналіз чинників, які впливають на ефективність функціонування системи управління військами у ході ведення стабілізаційної операції. Збірник наукових праць національної академії Державної прикордонної служби України. Серія: військові та технічні науки. Хмельницький: 2016. № 4(70). С. 133-142.

7. Михалевич В. Е. Аналіз факторів, що впливають на ефективність функціо- нування інформаційного забезпечення АСУ. Труди університету. Збірник наукових праць. Національний університет оборони України ім. Івана Черняховського 2018 №4 (149) С. 105.

8. Шолудько В. Г. Організація військового зв'язку: навч. посіб. / В. Г. Шолудько, М. Ю. Єсаулов, М. О. Вакуленко, Т. Г. Рурський К.: МО України ВІTI, 2017. - 281 с.

9. Артилерійська розвідка: Підручник/[П. П. Ткачук. Ю. Є. Репіло, О. П. Красюк та інші]. - Львів: АСВ, 2014. - 343 с.

10. Ткаченко В. А., Полішко С. В., Сокуренко В. В., Таранець О. М. Аналіз стану системи артилерійської розвідки оперативнотактичного рівня та пропозиції по їі вдосконаленню $з$ урахуванням досвіду АТО (ООС) / В. А. Ткаченко, С. В. Полішко, В. В. Сокуренко, О. М. Таранець // Труди університету. Збірник наукових праць. Національний університет оборони України ім. Івана Черняховського. 2019. № 1 (151). С. 60-69.

11. Стужук П. І. Підвищення ефективності артилерійської розвідки в оборонній операції армійського корпусу. Дисертація на здобуття наукового ступеня кандидата військових наук.

12. Адаменко М. В., Ільяшов О. А. Оцінювання оперативності функціонування системи артилерійської розвідки в інтересах вогневого ураження противника 
ракетними військами і артилерією. Збірник наукових праць Центру воєнностратегічних досліджень НУОУ імені Івана Черняховського 2017. №2(60). С. 109.

13. Кулаков Ю. А., Омелянский С. В. КЗО Компьютерные сети. Выбор, установка, использование и администрирование / Кулаков Ю. А., Омелянский С.В. К.: Юниор, 1999. - 544 с., ил. Ярош С. П. Теоретичні основи побудови та застосування розвідувально-управляючих інформаційних систем протиповітряної оборони: монографія / С.П. Ярош; за ред. І.О. Кириченка. -Х.: ХУПС, 2012.-512 с.

14. Загорка О. М. Визначення потрібної кількості особового складу об'єднаного командного пункту угрупування військ / О. М. Загорка, А. А. Корецький, А. К. Павліковський, І. О. Загорка // Національний університет оборони України ім. Івана Черняховського. Труди університету. Збірник наукових праць. 2018 - №2 (147) - С. 35 - 43.

\title{
Анализ факторов, влияющих на функционирование пунктов управления артиллерийской разведки
}

\author{
Александр Таранец ${ }^{\text {; }}$ Николай Дорофеев ${ }^{\text {B }}$ \\ А Научно-исследовательский центр ракетных войск и артиллерии, Сумы, ведущий научный сотрудник научно-исследовательского отдела \\ (научного сопровождения боевого применения ракетных войск и артиллерии), e-mail: ant505@ukr.net \\ в Центральный научно-исследовательский институт вооружения и военной техники ВСУ., г. Киев, адъюнкт, e-mail: dorofeev83@meta.ua
}

\section{Аннотация}

Характерными тенденциями современной вооруженной борьбы, которые непосредственно влияют на работу пунктов управления артиллерийской разведки, в целом можно считать: переход к сетецентрической концепции ведения военных действий; рост пространственного размаха и динамизма вооруженной борьбы; глобализацию систем разведки, управления и навигации; возрастание роли информационной борьбы, кибернетических действий в конфликтах и войнах будущего; сокращение временных показателей на подготовку к ведению военных действий; обеспечение качественно нового уровня информационной совместимости систем разведки, контроля, навигации, управления и различных ударных средств и комплексов; интеграцию средств разведки, поражения, управления и радиоэлектронной борьбы в радиоэлектронной-огневые системы, обеспечиваются информацией и управляются в масштабе времени, близком к реальному. При оценке эффективности применения пункта управления артиллерийской разведкой необходимо выявить степень зависимости от объективных и субъективных факторов, установить механизм их влияния на функционирование.

В статье рассмотрены факторы, влияющих на функционирование пунктов управления артиллерийской разведки, которые предлагается разграничить на внешние и внутренние. Проведен анализ их взаимодействия.

Нарушение функционирования пунктов управления артиллерийской разведки приведет к невозможности централизованного управления системой артиллерийской разведки и отдельными органами разведки. Поэтому обязательно нужно учитывать влияние этих факторов с целью эффективного функционирования и, соответственно, эффективного огневого поражения противника артиллерией в целом.

Результаты анализа данных факторов возможно применить при формировании показателей эффективности функционирования пунктов управления артиллерийской разведки.

Анализ взаимодействия сил и средств артиллерийской разведки и средств огневого поражения ведущих, в военном отношении, стран мира предоставляет возможность изучения путей развития вооружения и военной техники для обеспечения создания разведывательно-информационной подсистемы ракетных войск и артиллерии. 
Ключевые слова: разведка, артиллерийская разведка, средства огневого поражения, пункт управления артиллерийской разведки, система боевого управления, разведывательно-огневой комплекс.

\title{
Analysis of factors affecting the functioning of artillery reconnaissance control posts
}

\author{
Alexander Taranetc ${ }^{A}$; Mykola Dorofeev ${ }^{B}$ \\ ${ }^{A}$ Missile Troops and Artillery Research Center, Sumy, leading researcher of the research department \\ (scientific support of combat use of missile troops and artillery), e-mail: ant505@ukr.net \\ ${ }^{B}$ Central Research Institute of Armaments and Military Equipment of the Armed Forces of Ukraine, \\ Kyiv, PhD student, e-mail: dorofeev83@meta.ua
}

\begin{abstract}
Typical trends in modern warfare, which directly affect the operation of artillery reconnaissance control points, can generally be considered: the transition to a network-centric concept of warfare; the growth of spatial scope and dynamism of armed struggle; globalization of intelligence, control and navigation systems; the growing role of information warfare, cybernetic actions in conflicts and wars of the future; reduction of timelines for preparation for military operations; ensuring a qualitatively new level of information compatibility of reconnaissance, control, navigation, command and control systems and various strike weapons and systems; integration of reconnaissance, destruction, control and electronic warfare means into electronic-fire systems, are provided with information and are managed in a time scale close to real. When assessing the effectiveness of the use of an artillery reconnaissance control point, it is necessary to identify the degree of dependence on objective and subjective factors, and establish a mechanism for their influence on functioning.

The article discusses the factors affecting the functioning of artillery reconnaissance control points, which are proposed to distinguish between external and internal. An analysis of their interaction.

The disruption of the functioning of the artillery reconnaissance control posts will lead to the impossibility of centralized control of the artillery reconnaissance system and individual intelligence agencies. Therefore, it is imperative to take into account the influence of these factors in order to function effectively and, accordingly, effectively fire the enemy with artillery as a whole.

The results of the analysis of these factors can be used in the formation of performance indicators for the functioning of artillery reconnaissance control centers.

An analysis of the interaction of forces and means of artillery reconnaissance and fire weapons of the leading, militarily, countries of the world provides an opportunity to study the development of weapons and military equipment to ensure the creation of reconnaissance and information subsystems of rocket troops and artillery.
\end{abstract}

Keywords: reconnaissance, artillery reconnaissance, firearms, artillery reconnaissance control point, combat control system, reconnaissance-fire complex.

\section{References}

1. Osnovy teorii upravleniya voyskami / pod red. P. K. Altukhova. Moscow: Voyennoye izdatel'stvo, 1984. $222 \mathrm{~s}$.

2. Verveyko B. M., Gul'bis S. K. Otsenka effektivnosti funktsionirovaniya sistemy upravleniya voyskami. Nauka i voyennaya bezopasnost. 2006. № 4.
3. Yarosh S. P. Teoreticheskiye osnovy pobuzhdeniy i zastarelykh rozovykh i informatsionnykh sistem prototipov oborony: monografiyaю Kharkiv: KHUPS, 2012. $512 \mathrm{~s}$.

4. Magas G. A. Tendentsií rozvitku zbroynoí botaniki u suchasnikh umovakh. Zbírnik nauchnykh prats' Natsíonal'noï akademiií 
Derzhavnoï prikordonnoï sluzhi Ukraïni. Seriya: víys'koví ta tekhníchní nauki. Khmel'nits'kiy: 2015. №1 (63). S. 79-95.

5. Sovmestnaya publikatsiya 6-0 «Doktrina podderzhki sistem komandovaniya, upravleniya, svyazi i komp'yuternykh sistem (C4) dlya sovmestnykh operatsiy». 1995. $88 \mathrm{~s}$.

6. Mozgoviy R. Analiza Chinnikova, kotoryy prinimayet vo vnimaniye effektivnost' funktsional'nykh sistem upravleniya i upravleniya pri operativnoy i / ili operativnoy rabote / R. Mozgoviy // Nauchnoissledovatel'skiy institut natsional'noy akademii derzhavnoy sluzhby Ukrainy. Seriya: víys'koví ta tekhníchní nauki. Khmel'nits'kiy: 2016. № 4 (70). S. 133-142.

7. Mikhalevich V. Ye. Analiticheskiy faktor, sposobstvuyushchiy effektivnomu funktsionirovaniyu informatsionnoy zablagovremennosti ASU. / V. Ye. Mikhalevich // Natsíonal'niy uníversitet oboroni Ukraïni im. Ívana Chernyakhovs'kogo. Trudi uníversitetu. Zbírnik naukovikh prats'. 2018 №4 (149) S. 105.

8. Sholud'ko V. G. Organízatsíya víys'kovogo zv'yazku: navch. posíb. / V. G. Sholud'ko, M. YU. Êsaulov, M. O. Vakulenko, T. G. Rurskiy. Kyiv: MO Ukraïni VÍTí, 2017. 281 s.

9. Artileríys'ka rozvídka: Pídruchnik / [P. P. Tkachuk. YU. Ê. Repílo, O. P. Krasyuk ta ínshí]. L'viv: ASV, 2014. $343 \mathrm{~s}$.

10. Tkachenko V. A., Políshko S. V., Sokurenko V. V., Taranets' O. M. Analiticheskoye oborudovaniye i operativno-rozysknyye operatsii operativno-takticheskogo razvitiya i reabilitatsii $v$ usloviyakh dosrochnoy podgotovki ATO (OOS) / V. A. Tkachenko, S. V. Políshko, V. V. Sokurenko, O. M. Taranets' // Natsíonal'niy natsional'nyy universitet oborony Ukrainy. Ívana Chernyakhovs'kogo. Trudi uníversitetu. Zbírnik naukovikh prats'. 2019. № 1 (151). S. 60-69.

11. Stuzhuk P. Í. Pedvishennya operativnoy artilleriyskoy roznitsy $v$ oboronnoy operatsii armeyskogo korpusa. Distsiplina $v$ nauke uchenoy stepeni kandidata nauk.

12. Adamenko M. V., Íl'yashov O. A. Otsenka operativnosti i funktsional'nosti sistem artilleriyskogo rozyska v Integral'nom tsentre protiv raketnykh voysk i artillerii / Adamenko M. V., Íl'yashov O. A. // Natsional'nyy nauchnyy tsentr Tsentrov voyennostrategicheskikh issledovaniy NUOU imeni Ivana Chernyakhovskogo 2017. №2 (60). S.109.

13. Kulakov YU. A., Omelyanskiy S. V. KZO Komp'yuternyye seti. Vybor, ustanovka, ispol'zovaniye i administrirovaniye / Kulakov YU. A., Omelyanskiy S.V. K .: Yunior, 1999. 544 S., II. Yarosh S. P. Teoreticheskiye osnovy pobuzhdeniy i zastarelykh rozovoupravlyayushchikh informatsionnykh sistem prototipov oborony: monografiya / S.P. Yarosh; za red. Í.O. Kirichenka. Kharkiv.: KHUPS, 2012.-512 s.

14. Zagorka O. M. Vizanennya potríbnoî kíl'kostí osobogo sklada ob'dnanogo komandnogo punkta ugrupuvannya víys'k / O. M. Zagorka, A. A. Korets'kiy, A. K. Pavlíkovs'kiy, í. O. Zagorka // Natsíonal'niy uníversitet oboroni Ukraîni im. Ívana Chernyakhovs'kogo. Trudi uníversitetu. Zbírnik naukovikh prats'. 2018 №2 (147) S. 35 - 43. 